\title{
Analisis Efektifitas PSBB Terhadap Perubahan Budaya Masyarakat Di Kecamatan Sidoarjo
}

\author{
Ayu Lucy Larassaty \\ Program Studi Manajemen, Universitas Nahdlatul Ulama Sidoarjo, Indonesia \\ Korespondensi*: larassaty.mnj@unusida.ac.id
}

\begin{abstract}
ABSTRAK
Penelitian ini bertujuan untuk 1) mengetahui besarnya efektifitas PSBB (Pembatasan Sosial Berskala Besar) terhadap budaya masyarakat di Kecamatan Sidoarjo dalam menghadapi Pandemi Covid-19, 2) mengetahui perubahan model budaya masyarakat dalam menghadapi Pandemi Covid-19 di Kecamatan Sidoarjo. Metode penelitian menggunakan metode survey. Teknik analisis data menggunakan empat metode yang terdiri dari editing, coding, tabulasi dan analisis data. Hasil penelitian ini menjelaskan bahwa pelaksanaan PSBB (Pembatasan Sosial Berskala Besar) masih belum efektif karena sosialisasi dan pemahaman protokol pencegahan Covid-19 masih belum tersampaikan dengan baik kepada masyarakat di Kecamatan Sidoarjo sehingga masih banyak yang tidak menghiraukan bahaya Covid-19 bagi masyarakat dengan berbagai alasan untuk keluar rumah dan tidak melaksanakan protokol pemerintah. Hal ini juga berpengaruh pada perubahan budaya masyarakat yang mengacu pada lima model budaya masyarakat yang di terapkan sekarang ini 1) the nature of human life, 2) the nature of human work, 3) the nature of human nature, 4) the nature of human time dan 5) the nature of human relations. Bentuk perubahan budaya masyarakat yang berdampak positif ditunjukkan dengan adanya perilaku kepedulian masyarakat akan lingkungan, kesehatan masyarakat sekitar, komunikasi melalui media sosial, gotong royong, saling mengingatkan, memiliki rasa tanggungjawab agar mencapai kesejahteraan bersama. Sedangkan wujud perubahan budaya yang berdampak negatif ditunjukkan dengan sikap orang putus asa sehingga menggunakan motif kriminalitas dalam memenuhi kebutuhan dan perekonomian serta kurangnya kepedulian terhadap lingkungan.
\end{abstract}

Kata kunci: PSBB (Pembatasan Sosial Berskala Besar), Budaya Masyarakat dan Covid-19

\begin{abstract}
This study aims to 1) determine the effectiveness of the PSBB (Large-Scale Social Limitation) on community culture in Sidoarjo District in dealing with the Covid-19 Pandemic, 2) knowing the changes in the cultural model of the community in dealing with the Covid-19 Pandemic in Sidoarjo District. The research method uses the survey method. Data analysis techniques using four methods consisting of editing, coding, tabulation and data analysis. The results of this study explain that the implementation of PSBB (Large-Scale Social Restrictions) is still not effective because the socialization and understanding of Covid-19 prevention protocols have not been conveyed well to the community in Sidoarjo District so there are still many who ignore the danger of Covid-19 for the community for various reasons to leave the house and not implement government protocol. This also affects the change in the culture of society which refers to the five models of community culture that are applied today 1) the nature of human life, 2) the nature of human work, 3) the nature of human nature, 4) the nature of human time and 5) the nature of human relations. The form of community culture change that has a positive impact is shown by the attitude of community awareness of the environment, the health of the surrounding community, communication through social media, mutual cooperation, mutual reminding, having a sense of responsibility in order to achieve mutual prosperity. While the form of cultural change that has a negative impact is shown by the attitude of people who are desperate so that they use criminal motives to meet their needs and the economy and a lack of concern for the environment.
\end{abstract}

Keywords: PSBB (Large-scale Social Limitation), Community Culture and Covid-19 


\section{PENDAHULUAN}

Februari 2020 Indonesia di gegerkan dengan salah satu wabah virus yang di kenal dengan sebutan Covid-19. Covid-19 ini bersal dari kota Wuhan di Negara Cina yang berimbas ke 118 Negara di dunia salah satunya adalah Indonesia yang bermula di daerah Jakarta kemudian merabah ke daerah Surabaya dan Sidoarjo. Penyebaran Covid-19 ini sangat cepat dimana data penyebaran Covid-19 di Kota Sidoarjo dapat ditunjukkan pada grafik di bawah ini:

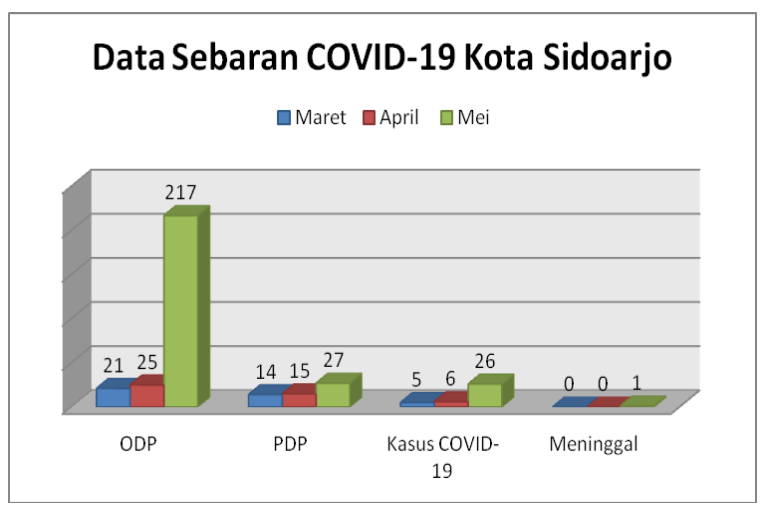

Gambar 1.

Sebaran COVID-19 di Kota Sidoarjo Sumber: Dinas Kesehatan Kabupaten Sidoarjo 2020

Berdasarkan gambar 1 diatas dapat menunjukkan peningkatan penyebaran Covid-19 yang harus di atisipasi oleh semua warga Kota Sidoarjo. Oleh karena itu berdasarkan kebijakan Pemerintah Daerah Kabuapaten Sidoarjo untuk memutus mata rantai penyebaran Covid-19 ini di berlakukkan 3 metode yaitu PSBB (Pembatasan Sosial Bersekala Besar),
Sosial Distancing dan Physical Distancing.

Tiga metode tersebut berdampak positif dan negatif dimana dengan adanya peningkatan jumlah penyebaran Covid-19 ini berdampak negative bagi semua masyarakat ketika banyak masyarakat yang harus Work From Home, di liburkan sementara, PHK dan akhir-akhir ini di berlakukkan metode PSBB (Pembatasan Sosial Berskala Besar). Perlakuan metode PSBB (Pembatasan Sosial Berskala Besar) ini diberlakukkan di 18 Kecamatan di Kota Sidoarjo akan tetapi hnya 14 Kecamatan saja yang melaksanakan dan kategori zona merah (Suparno, 2020). Berdasarkan hasil survey sementara tiga hari setelah pelaksanaan PSBB (Pembatasan Sosial Berskala Besar) menunjukkan bahwa budaya masyarakat yang harus Stay At Home belum terlaksana karena banyak orang yang masih keluar rumah tidak mematuhi peraturan serta masih banyak tempat hiburan dan warung yang tidak memperdulikan protokol pemerintah dalam penanggulangin covid-19 ini masih sangat minim karena hingga saat ini pasien yang positif covid-19 masih terbilang tinggi dan pasien yang di kategorikan PDP sebesar 203 orang dan kategori ODP sebesar 784 orang (Agriesta, 2020).

Menurut (Buana, 2020) menjelaskan bahwa budaya masyarakat yang tidak 
peduli terhadap himbauan tersebut merupakan salah satu sikap seseorang yang memiliki emosianal bias dimana setiap orang berfikir bahwa dia faham dengan kondisi pandemi sekarang ini padahal secara nyata tidak faham akan kondisi tersebut. Hasil penelitian ini sejalan dengan penelitian yang dilakukkan oleh (Schwartz, 2009) menjelaskan terdapat tujuh dimensi yang digunakan untuk melihat budaya yaitu: Harmoni, Kedutaan, Penguasaan, Efektif Otonomi, Intellektual Otonomi, Egalitarianisme berdasarkan dari hasil teori tersebut menunjukkan bahwa budaya masyarakat Sidoarjo pada awalnya memang dikategorikan berdasarkan tujuh dimensi, akan tetapi dimensi tersebut mengalami kemunduran. Dimana hampir semua negara berjuang untuk memperlambat penularan penyakit dengan menguji \& merawat pasien, mengkarantina orang yang dicurigai melalui pelacakan kontak, membatasi pertemuan besar akan tetapi tidak banyak yang memperdulikan karena masih kurangnya kesadaran pada masing-masing individu (Chakraborty \& Maity, 2020).

Berdasarkan fenomena yang terjadi di atas maka dalam penelitian ini bertujuan untuk 1) mengetahui besarnya efektifitas PSBB (Pembatasan Sosial Berskala Besar) terhadap budaya masyarakat di Kecamatan Sidoarjo dalam menghadapi Pandemi
Covid-19, 2) mengetahui perubahan model budaya masyarakat dalam menghadapi Pandemi Covid-19 di Kecamatan Sidoarjo. Adapaun manfaat dari penelitian ini adalah 1) agar dapat mengetahui besarnya efektifitas PSBB (Pembatasan Sosial Berskala Besar) terhadap budaya masyarakat di Kecamatan Sidoarjo dalam menghadapi Pandemi Covid-19, 2) agar mengetahui perubahan model budaya masyarakat dalam menghadapi Pandemi Covid-19 di Kecamatan Sidoarjo.

\section{METODE}

Ruang lingkup pada penelitian ini menjelasakan bahwa metode penelitian yang digunakan adalah metode survey. Hipotesis pada penelitian ini menunjukkan bahwa 1). PSBB efektif terhadap terhadap budaya masyarakat di Kecamatan Sidoarjo dalam menghadapi Pandemi Covid-19 2). Terdapat perubahan model budaya masyarakat dalam menghadapi Pandemi Covid-19 di Kecamatan Sidoarjo.

Pengumpulan data pada penelitian ini menggunakan kuisioner dan kepustakaan dengan menggunakan skala Guttman. Penarikan sampel pada penelitian ini menggunakan metode nonprobability sampling dengan purposive sampling dimana sampel di nilai sebagai sampel yang memiliki kriteri sebagai warga Kota Sidoarjo dengan jumlah Populasi sebesar 
sebesar 228 orang di Kecamatan Sidoarjo responden dengan hitungan slovin sebagai berikut :

$$
\begin{aligned}
& \mathrm{n}=\frac{\mathrm{N}}{1+\left(\mathrm{Ne}^{2}\right)} \\
& \mathrm{n}=\frac{228}{1+\left(228.0 .05^{2}\right)} \\
& \mathrm{n}=145
\end{aligned}
$$

Berdasarkan perhitungan slovin diatas bahwa sampel yang digunakan dalam penelitian ini sebesar 145 responden. Adapun teknik analisis data yang digunakan dalam penelitian ini menggunakan empat metode yang terdiri dari editing, coding, tabulasi dan analisis data kuantitatif.

\section{HASIL DAN PEMBAHASAN}

Harsil survey pada penelitian ini ditunjukkan berdasarkan identifikasi responden yang digunakan peneliti sebagai sampel dalam penelitian ini yang ditunjukkan sebagai berikut:

\section{Hasil survey responden berdasarkan jenis kelamin.}

Berdasarkan hasil survey melalui google formulir dapat ditunjukkan hasil survey responden berdasarkan jenis kelamin sebagai berikut:

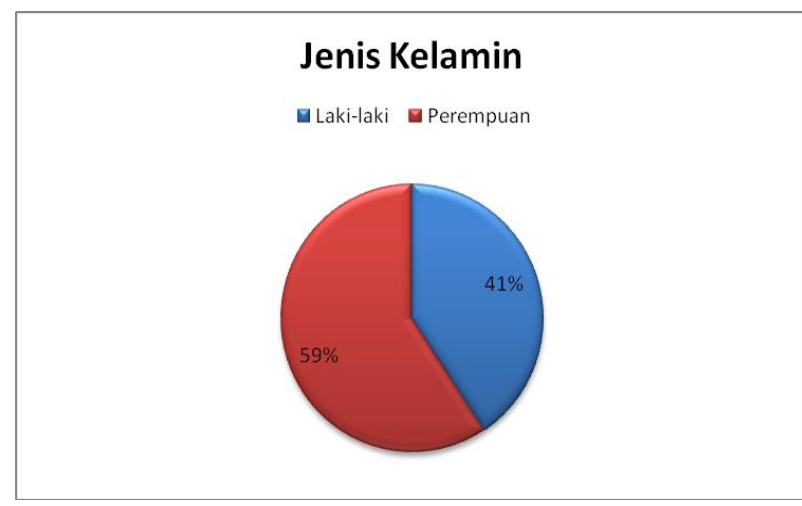

\section{Gambar 2}

Hasil Survey Responden Berdasarkan Jenis Kelamin

Sumber: Data diolah Peneliti 2020

Hasil survey pada gambar 2 diatas dapat dijelaskan bahwa responden berpartisipasi mengisi kusioner berdasarkan jenis kelamin laki-laki sebanyak $41 \%$ sedangkan perempuan sebanyak $59 \%$.

\section{Hasil survey responden berdasarkan} Usia

Berdasarkan hasil survey melalui google formulir dapat ditunjukkan hasil survey responden berdasarkan usia sebagai berikut:

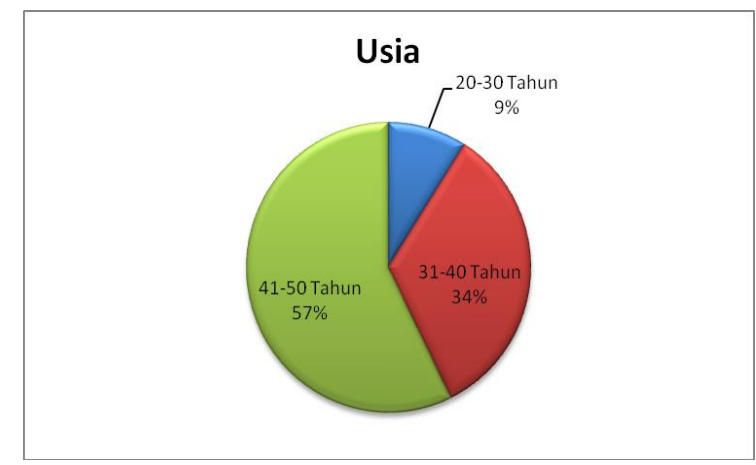

\section{Gambar 3}

Hasil Survey Responden Berdasarkan Usia

Sumber: Data diolah Peneliti 2020 
Hasil survey pada gambar 3 diatas dapat dijelaskan bahwa responden berpartisipasi mengisi kusioner berdasarkan usia 20-30 Tahun sebanyak 9\%, berusia 31- 40 Tahun sebanyak 34\% sedangkan sisanya berusia 41-50 Tahun sebanyak $57 \%$.

\section{Hasil survey responden berdasarkan} Pekerjaan

Berdasarkan hasil survey melalui google formulir dapat ditunjukkan hasil survey responden berdasarkan pekerjaan sebagai berikut:

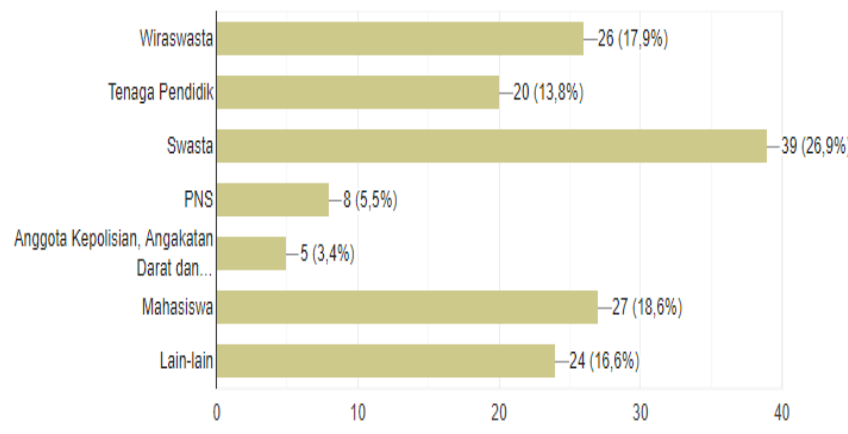

Gambar 4

Hasil Survey Responden Berdasarkan Pekerjaan

Sumber: Data diolah Peneliti 2020

Hasil survey pada gambar 4 diatas dapat dijelaskan bahwa responden berpartisipasi mengisi kusioner berdasarkan jenis pekerjaan wiraswasta sebanyak $17,9 \%$, tenaga pendidik sebanyak $13,8 \%$, Swasta sebanyak $26,9 \%$, PNS sebanyak 5.5\%, Anggota Kepolisian dan Angkatan Darat dan Laut sebanyak 3,5\%, Mahasiswa sebanyak 18,6\% sedangkan sisanya kategori lain-lain sebanyak $16,6 \%$.
Besarnya efektifitas PSBB terhadap budaya masyarakat di Kecamatan Sidoarjo dalam menghadapi Pandemi Covid-19 di Kecamatan Sidoarjo.

Berdasarkan hasil survey masyarakat di Kecamatan Sidoarjo tidak semua faham terkait metode PSBB (Pembatasan Sosial Berskala Besar) yang diberlakukkan dari tanggal 28 April 2020 hingga 11 Mei 2020. Hal ini dipaparkan berdasarka hasil survey peneliti dapat

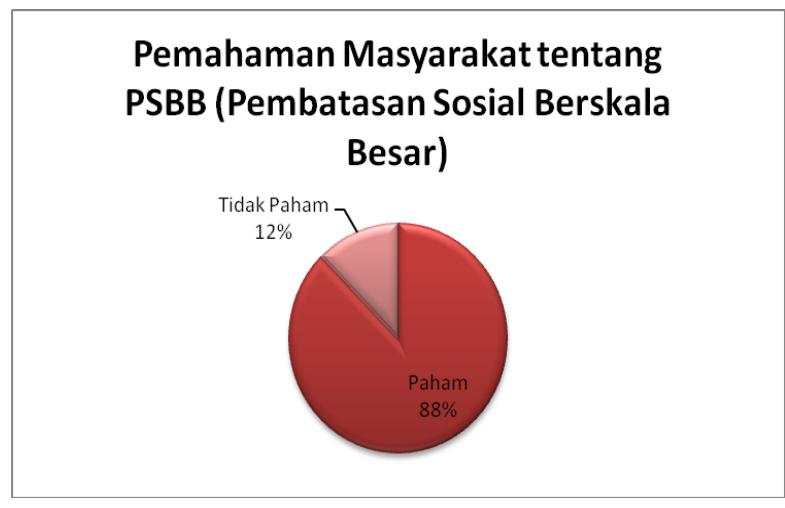

ditunjukkan sebagai berikut:

\section{Gambar 5}

Hasil Survey Pemahaman Masyarakat tentang PSBB (Pembatasan Sosial Berskala Besar)

Sumber: Data diolah Peneliti 2020

Hasil survey pada gambar 5 diatas dapat dijelaskan bahwa dari 145 masyarakat di Kecamatan Sidoarjo 30\% masyarakat masih belum paham apa makna dan perlakuan metode PSBB (Pembatasan Sosial Berskala Besar) yang telah diimplementasikan di lingkungan, sedangkan sisanya $70 \%$ paham adanya metode PSBB (Pembatasan Sosial Berskala Besar) dalam pemutusan mata 
rantai penyebaran Covid-19, hal ini di sebabkan karenya kurangnya sosialisasi dari pemerintahan desa tempat masingmasing masayarakat tinggal hal ini dapat diketauhui melalui hasi survey yang di tunjukkan sebagai berikut:

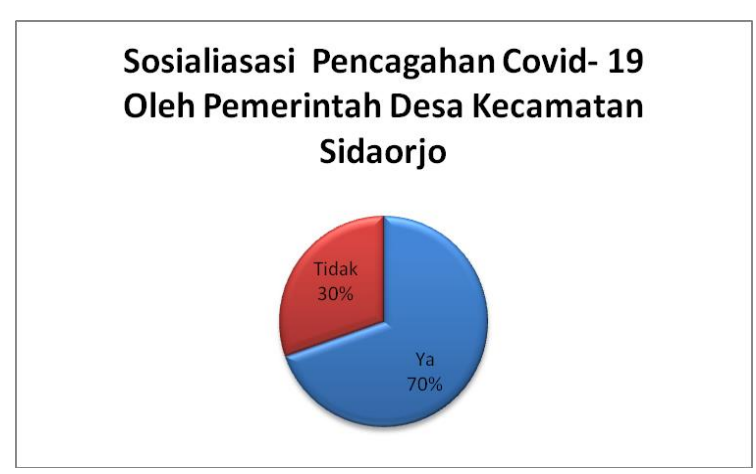

Gambar 6

Hasil Survey Sosialisasi Pemerintah Desa Tentang Covid

Sumber: Data diolah Peneliti 2020

Hasil survey pada gambar 6 diatas dapat dijelasakan bahwa jawaban desa tempat tinggal masing-masing masyarakat di Kecamatan Sidoarjo sudah memberikan sosialisasi terkait dengan apa itu Covid-19, budaya cuci tangan, bagaimana penanggulanginya Covid-19 penerapan sosisal distancing, work from home, pemberian bak air atau kran di depan rumah masing-masing masyarakat akan tetapi $30 \%$ jawaban masyarakat mengatakan bahwa pemerintah desa belum memberikan sosialisasi kepada masayarakat sehingga muncullah sikap kurang kepedulian akan tetapi masayarakat banyak saling belajar dan mendapat informasi dari desa lain maupun media massa maupun elektronik. Berdasarkan hasil survey dapat ditunjukkan implementasi protokol pemerintah dan pelaksanaan PSBB (Pembatasan Sosial Berskala Besar) di Kecamatan Sidoarjo yang digunakan untuk memutus mata rantai covid-19 dapat dijelaskan sebagai berikut:

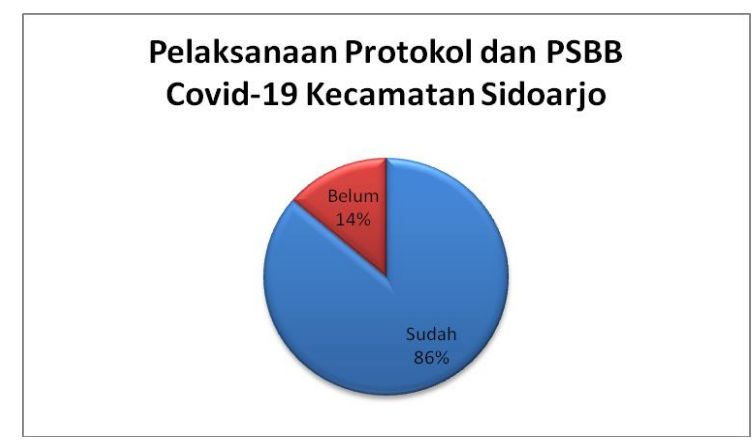

Gambar 7

Hasil Survey Pelaksanan Protokol dan PSBB (Pembatasan Sosial Berskala Besar) Covid-19 Kecamatan Sidoarjo.

Sumber: Data Diolah Peneliti 2020

Hasil survey pada gambar 7 diatas dapat dijelaskan bahwa pelaksanaan metode PSBB (Pembatasan Sosial Berskala Besar) yang di bentuk dalam suatu media cetak (Benner, Pamflet) maupun penyemprotan desinfektan yang dilakukkan di setiap rumah ataupun di setiap protokol jalan raya sudah di lakukkan oleh masyarakat sebesar $86 \%$ sedangkan $14 \%$ masyarakat masih belum melaksanakan protocol (keluar rumah dengan menggunakan masker, cuci tangan, sosisal distancing, work from home dan pelaksanaan PSBB (Pembatasan Sosial Berskala Besar) untuk pencegahan Covid- 
19 di Kecamatan Sidoarjo yang dilakukkan menutup jalan secara bergantian pada jam 21.00 - 04.00 WIB. Hal ini tidak menjadikan efek jera pada masayarakat masih banyak yang belum mematuhi meskipun pemerintah sudah menginformasikan bahwa masyarakat di Kabupaten Sidoarjo yang terdampak kasus Covid-19 meningkat dan tidak hanya itu razia yang dilakukkan pada setiap tempat hiburan maupun tempat ibadah tidak dihiraukan, hal ini munculnya kurang kesadaran masyarakat terhadap diri sendiri dan lingkungan sekitar, dimana masih banyak masyarakat melakukkan aktivitas di luar rumah sehingga pelaksanaan PSBB (Pembatasan Sosial Berskala Besar) belum dilakukkan.

Oleh karena itu berdasarkan hasil survey yang dilakukkan oleh peneliti bahwa kurangnya kesadaran masyarakat tersebut dilakukkan dengan berbagai alasan yang dijelaskan pada gambar di bawah ini:

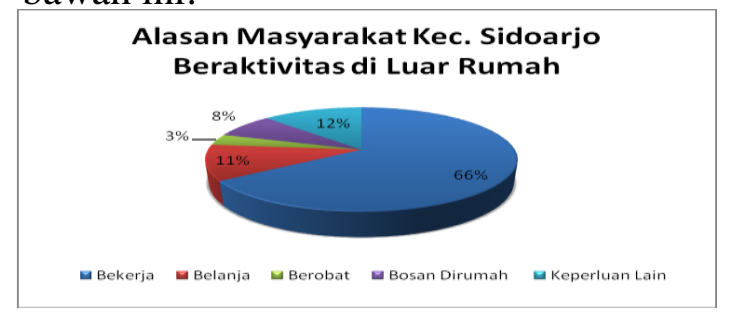

\section{Gambar 8}

Hasil Survey Alasan Masyarakat Beraktivitas di Luar Rumah

Sumber: Data diolah Peneliti 2020
Hasil survey pada gambar 8 diatas dapat dijelaskan bahwa masih banyak masayarakat yang masih memikirkan tuntutan ekonomi untuk memenuhi kebutuhan sehari-harinya sebesar 66\%, aktivitas berbelanja sebesar $11 \%$, aktivitas keperluan lain sebesar $12 \%$, masih bnyak aktivitas berkerumun di luar rumah dengan alasan bosan di rumah sebesar $8 \%$ dan sisanya sebagian masyarakat harus berobat sebesar 3\%. Hal ini diartikan bahwa efektivitas pelaksanaan PSBB (Pembatasan Sosial Berskala Besar) terbilang masih belum efektif karena masih banyak masyarakat yang belum mengimplementasikan protocol pencegahan Covid-19 dan pelaksanaan PSBB (Pembatasan Sosial Berskala Besar) dan hal ini juga berdampak pada budaya msayarakat Kecamatan Sidoarjo yang mulai berubah.

Dampak perubahan budaya ini berpengaruh terhadap perubahan social pada diri masyarakat yang berbentuk komunikasi, cara berfikir dan perilaku. Hal ini dijelaskan berdasarkan survey yang dilakukkan peneliti menunjukkan pada gambar di bawah ini: 


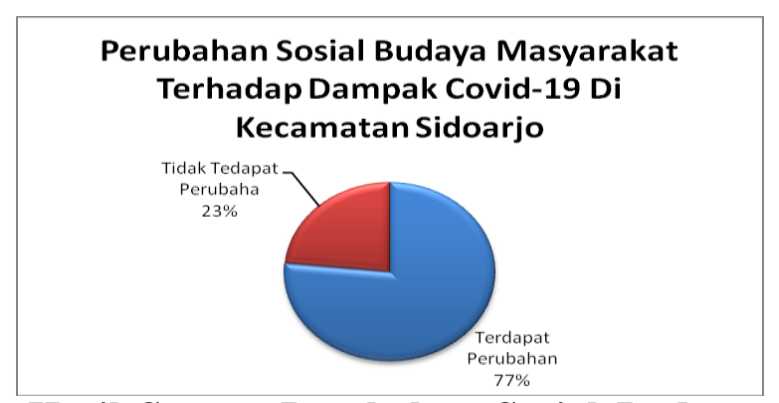

Hasil Survey Perubahan Sosial Budaya Masayarakat

Sumber: Data diolah Peneliti 2020

Hasil survey pada gambar 9 diatas dapat dijelaskan bahwa perubahan social masyarakat dengan adanya Covid-19 ini mempunyai nilai sebesar $77 \%$ yang diartikan bahwa kepedulian masyarakat akan lingkungan, kesehatan dan masyarakat di sekitar, komunikasi melalui media social, gotong royong, saling mengingatkan, memiliki rasa tanggungjawab agar mencapai kesejahteraan bersama. Sedangkan social budaya msayarakat tidak terdapat perubahan sebesar $23 \%$ dimana terdapat perubahan negatif yang ditunjukkan bahwa masayarakat Kecamatan Sidoarjo yang terkenal budaya adat yang santun akan tetapi sekarang tidak berpengaruh karena di tutupi dengan masker dan banyak orang lebih mengutamakan emosional daripada kesabaran sehingga berakibat ketidak pedulian terhadap lingkungan sekitar sehingga berakibat individual yang ditimbulkan karena sulitnya komunikasi untuk menumbuhkan rasa kepedulian, saling menolong agar mencapai kesejahteraan bersama dan banyaknya tindakan kriminalitas karena untuk memenuhi kebutuhan dan perekonomiannya. Berdasarkan hasil survey diatas dapat sejalan dengan teori yang di kemukakan oleh Pasaribu, (2015:99) menjelaskan bahwa terdapat 5 orientasi model budaya masyarakat yang berpengaruh terhadap perubahan budaya masyarakat yang dapat ditunjukkan pada gambar di bawah ini:

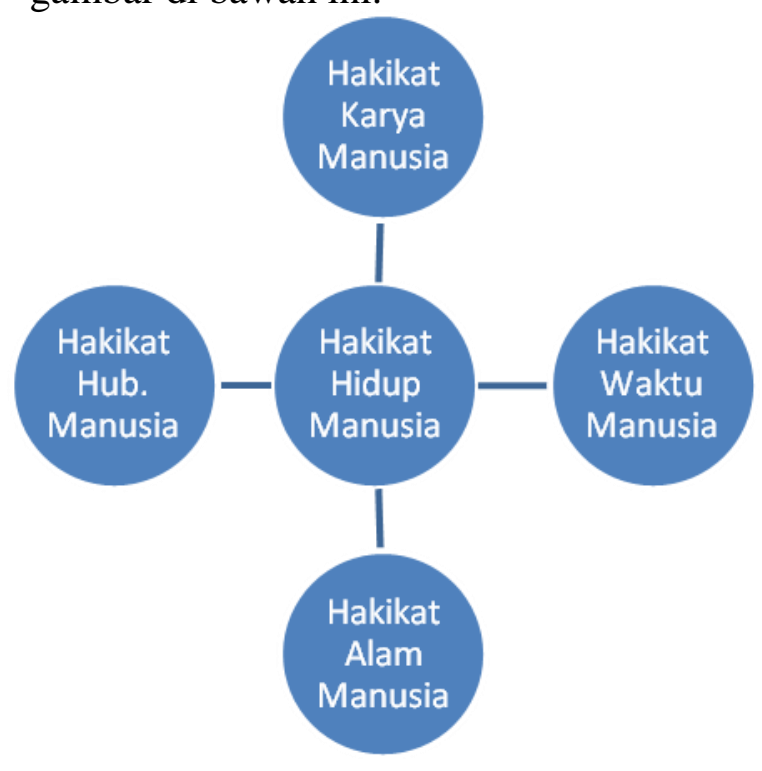

\section{Gambar 10 \\ Orientasi Nilai Budaya Masayarakat Sumber: Pasaribu, (2015:99)}

SIMPULAN

Berdasarkan hasil survey diatas maka penelitian ini dapat disimpulkan bahwa bahwa pelaksanaan PSBB (Pembatasan Sosial Berskala Besar) masih belum efektif karena sosialisasi dan pemahaman protokol pencegahan Covid-19 masih belum 
tersampaikan dengan baik kepada masyarakat di Kecamatan Sidoarjo sehingga masih banyak yang tidak menghiraukan bahaya Covid-19 bagi masyarakat dengan berbagai alasan untuk keluar rumah dan tidak melaksanakan protokol pemerintah. Hal ini juga berpengaruh pada perubahan budaya masyarakat yang mengacu pada lima model budaya masyarakat yang di terapkan sekarang ini 1) the nature of human life, 2) the nature of human work, 3) the nature of human nature, 4) the nature of human time dan 5) the nature of human relations. Bentuk perubahan budaya masyarakat yang berdampak positif ditunjukkan dengan adanya perilaku kepedulian masyarakat akan lingkungan, kesehatan masyarakat sekitar, komunikasi melalui media sosial, gotong royong, saling mengingatkan, memiliki rasa tanggungjawab agar mencapai kesejahteraan bersama. Sedangkan wujud perubahan budaya yang berdampak negatif ditunjukkan dengan sikap orang putus asa sehingga menggunakan motif kriminalitas dalam memenuhi kebutuhan dan perekonomian serta kurangnya kepedulian terhadap lingkungan.

Adapun saran yang harus dilakukkan oleh pemerintah Kabapuaten Sidoarjo adalah lebih menekankan kebijakan agar masyarakat mengalami efek jera serta memberikan pemahaman kepada masyarakat dalam bentuk sosialisasi jika pimpinan desa sesuai kecamatan masingmasing bagi yang tidak menyampaikan sosialisasi dan pelaksanaan protocol dan PSBB maka desa tersebut dikenakan denda begitu juga sebaliknya jika masayrakat tidak patuh maka bisa di kenakan denda dan sanksi tegas dan untuk masyarakat Kecamatan Sidoarjo agar lebih peduli dan sadar bahwa virus yang berbahaya ini dapat hilang jika kesadaran yang di munculkan dari diri sendiri.

\section{DAFTAR PUSTAKA}

Agriesta, D. (2020). Sepekan Penerapan PSBB Sidoarjo, Warga Masih Keluyuran dan Nongkrong di Warung. Kompas.Com. Retrieved from

https://regional.kompas.com/read/202 0/05/06/12352991/sepekanpenerapan-psbb-sidoarjo-wargamasih-keluyuran-dan-nongkrong-di

Buana, D. R. (2020). Analisis Perilaku Masyarakat Indonesia dalam Menghadapi Pandemi Virus Corona (Covid-19) dan Kiat Menjaga Kesejahteraan Jiwa. SALAM: Jurnal Sosial Dan Budaya Syar-I, 7(3). https://doi.org/10.15408/sjsbs.v7i3.15 082

Chakraborty, I., \& Maity, P. (2020). COVID-19 outbreak: Migration, effects on society, global environment and prevention. Science of the Total Environment, 728, 138882. https://doi.org/10.1016/j.scitotenv.202 0.138882 
Pasaribu, R. B. F. (2015). Kebudayaan dan Masyarakat. Semarang: Universitas Dian Nuswantoro.

Schwartz, S. H. (2009). A theory of cultural value orientations: Explication and applications. Comparative Sociology, 5(2-3), 173219.

Suparno. (2020). 14 dari 18 Kecamatan di Sidoarjo akan Diberlakukan PSBB. Detik News. Retrieved from https://news.detik.com/berita-jawatimur/d-4983761/14-dari-18kecamatan-di-sidoarjo-akandiberlakukan-psbb

\section{PROFIL SINGKAT}

Nama Ayu Lucy Larassaty, SE., MM, saya lahir di Sidoarjo tgl 12 Januari 2020, pendidikan terakhir saya Sarjana Strata 2 saya mengajar di Universitas Nahdlatul Ulama Sidoarjo aktivitas saya saat ini sebagai Dosen Tetap Yayasan di Fakultas Ekonomi. 